\title{
LOAD DYNAMIC METHODS TO PREVENT LIQUEFACTION AT YOGYAKARTA INTERNATIONAL AIRPORT INDONESIA
}

\author{
Edy Purwanto and Annisa Yaumil Akhiri
}

Civil Engineering Department, Universitas Islam, Indonesia

\begin{abstract}
Liquefaction is a phenomenon loss the strength of the soil due to a cyclic load, like the load caused by an earthquake, which causes the soil to deform from solid to liquid. occurs in saturated soil due to increased pore water pressure and effective reduction of soil stress and also reduces the shear strength of the soil. This researchhas purpose to determine the potential of liquefaction that can occur and how to prevention it with Dynamic Compaction. This research is located in the Yogyakarta International Airport Development Project (YIA). This research starts from collect of SPT and CPT soil data and laboratory data runway, Development Project for testing CSR (Cyclic Stress Ratio) and CRR (Cyclic Resistance Ratio) and comparing results before and after compaction. The results showed that there was before soil reinforcement, some soil layers at each review point still have the potential for liquefaction. However, after soil compaction with dynamic compaction, it can be concluded that all points of observation are safe from liquefaction potential because all points have a Safety Factor $>1$ and has a value $\left(N_{1}\right) 60 \geq 30$ classified as unliquefied soil. The liquefaction zone is at varying depths ranging from 2 - 6 meters. Dynamic load method test can prevent liquefaction on sandy soil
\end{abstract}

Keywords: Liquefaction, Dynamic Compaction, CPT, SPT, Earthquake, Airport

Cite this Article: Edy Purwanto and Annisa Yaumil Akhiri, Load Dynamic Methods to Prevent Liquefaction at Yogyakarta International Airport Indonesia, International Journal of Civil Engineering and Technology, 11(8), 2020, pp. 1-13.

https://iaeme.com/Home/issue/IJCIET?Volume $=11 \&$ Issue $=8$

\section{INTRODUCTION}

The Indonesian government is currently building an international airport in Yogyakarta. The international airport is named Ypgyakarta International Airport (YIA). The runway of the NYIA) has a length of 3,250 meters, located 400 meters from the shoreline and has greater potential for liquefaction. The Yogyakarta International Airport (YIA) Development Project has the potential for liquefaction in the area, because the position of the runway which is 400 meters from the shoreline has a greater potential for liquefaction. 
Lequefaction is the process of removing water from the soil pores caused by dynamic forces (earthquakes). As a result there is a reduction in the effective stress of the soil so that the carrying capacity of the soil will decrease.

Earthquakes cause cyclic loads, the potential for liquefaction will tend to occur in watersaturated fine grained soils. Referring to the liquefaction phenomenon that occurs, it is important to analyze this potential, where it is located on the beach. This is also the background for analyzing the potential for liquefaction in the Yogyakarta International Airport (YIA) Development Project. The soil investigation conducted at several points located at the YIA runway location (Figure 1.)

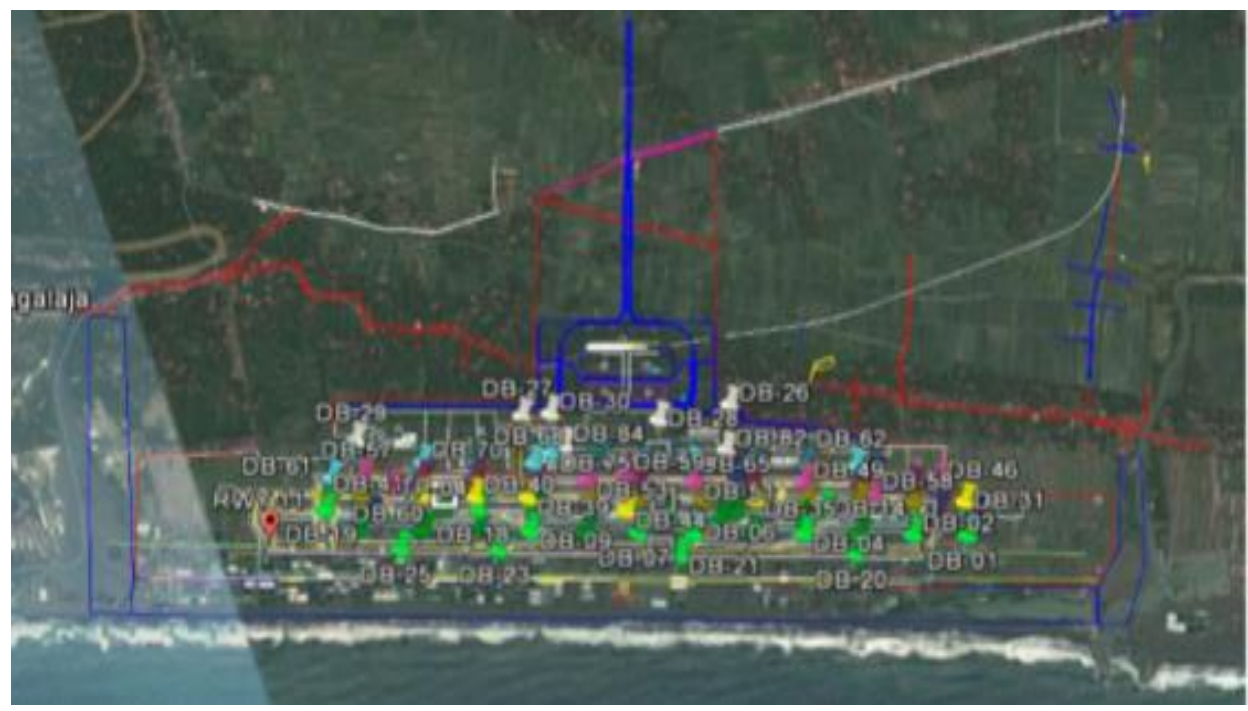

Figure 1 Location of the Geotechnial Survey

(Source : PPBIY, 2017)

This research took 12 points scattered in the airport area, but in this research only 2 points of DB01 test and CPT01 test are shown without dynamic load and dynamic load.

The research is located in the Yogyakarta Indonesia. Based on the Map of the Indonesian Earthquake Region SNI 1726-2012 the Yogyakarta area has a PGA value of $0.4-0.5 \mathrm{~g}$ and taken PGA $=0.4 \mathrm{~g}$. Details can be seen in Figure 2 below.

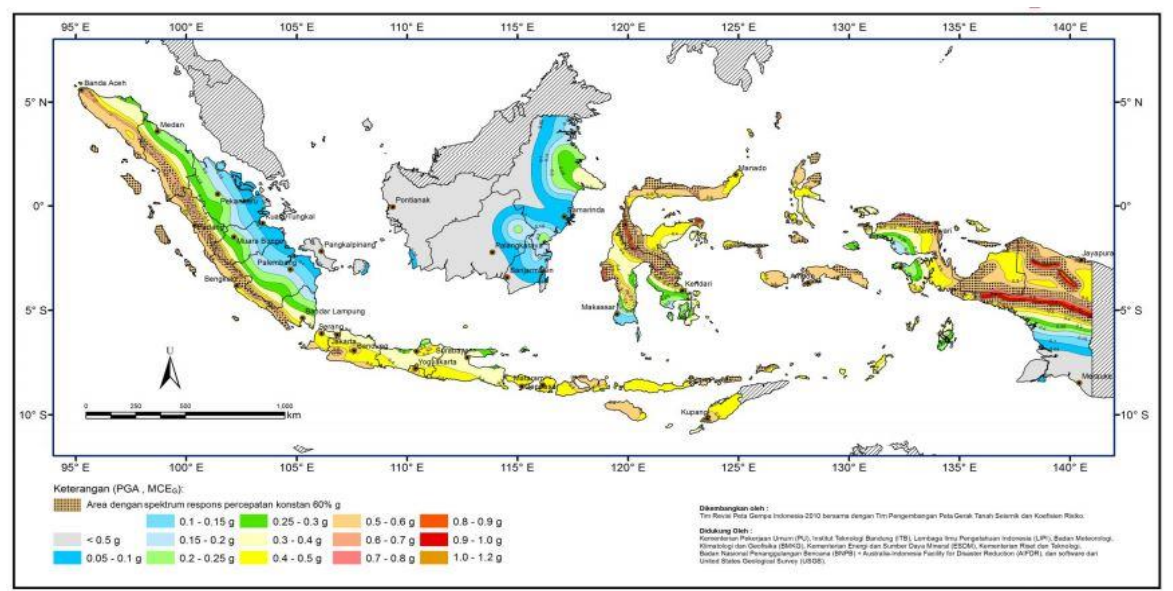

Figure 2 Map of the Indonesian Earthquake Area

(Sumber: SNI 1726-2012) 
The paper presents the research to evaluate the potential liquefaction based on SPT, CPT data before and after Dynamic Compaction Load applicated.

\section{LIQUEFACTION}

Liquefaction is a phenomenon of loss of soil strength due to earthquake vibrations. At the time of vibration, the sand layer turns into liquid so that it is unable to support the building loads inside or above, which are caused by cyclic loads during an earthquake so that the pore water pressure rises near or exceeds the vertical stress. As the water pressure increases, the distance between sand particles becomes increasingly tenuous, so that the total strength decreases dramatically.

\subsection{Method of Liquefaction Potential Evaluation}

Evaluation of liquefaction potential by conducting cyclic load tests on undisturbed soil samples or by measuring the characteristics of liquefaction on soils using several test procedures in the field. This research aims to obtain the results of the potential value of liquefaction from field test results, namely SPT and CPT. Basically standard liquefaction evaluation procedures include cyclic stress ratio (CSR) and cyclic resistivity (CRR) values that can be obtained from CPT and SPT.

\subsubsection{CRR Method (Cyclic Resistance Ratio Method)}

The steps that must be taken to get the CRR value from the SPT data in Equation 1.

$$
\left(\mathrm{N}_{1}\right)_{60}=\mathrm{N}_{\mathrm{m}} \times \mathrm{C}_{\mathrm{N}} \times \mathrm{C}_{\mathrm{E}} \times \mathrm{C}_{\mathrm{B}} \times \mathrm{C}_{\mathrm{R}} \times \mathrm{C}_{\mathrm{S}}
$$

where :

(N1) $60=\mathrm{N}$-SPT value corrected for the field testing procedure

$\mathrm{Nm}=$ Standard penetration resistance value

$\mathrm{CN}=$ factor normalization of $\mathrm{Nm}$ with overburden stresses in general (Table 1 and 2)

$\mathrm{CE}=$ correction hammer energy ratio

$\mathrm{CB}=$ correction for hole diameter

$\mathrm{CR}=$ length correction factor

$\mathrm{CS}=$ correction for the sample

Table 1 Correction Factors of SPT Value

\begin{tabular}{|c|c|c|c|}
\hline Factor & Tool Variable & Symbol & Correction \\
\hline \multirow[t]{2}{*}{ Total Stress } & & $\mathrm{C}_{\mathrm{N}}$ & $\left(\frac{P a}{\sigma v o^{\prime}}\right)^{0,5}$ \\
\hline & & $\mathrm{C}_{\mathrm{N}}$ & $\mathrm{Cn}$ \\
\hline \multirow{3}{*}{ Energy Ratio } & Hammer Donat & $\mathrm{C}_{\mathrm{E}}$ & $0,5-1,0$ \\
\hline & Safety Hammer & $\mathrm{C}_{\mathrm{E}}$ & $0,7-1,2$ \\
\hline & Automatic Hammer & $\mathrm{C}_{\mathrm{E}}$ & $0,8-1,3$ \\
\hline \multirow{3}{*}{ Hole Diameter } & $65-115 \mathrm{~mm}$ & $\mathrm{C}_{\mathrm{B}}$ & 1 \\
\hline & $150 \mathrm{~mm}$ & $\mathrm{C}_{\mathrm{B}}$ & 1,05 \\
\hline & $200 \mathrm{~mm}$ & $\overline{C_{B}}$ & 1,15 \\
\hline \multirow{5}{*}{ Rod length } & $<3 \mathrm{~m}$ & $\mathrm{C}_{\mathrm{R}}$ & 0,75 \\
\hline & $3-4 m$ & $\mathrm{C}_{\mathrm{R}}$ & 0,8 \\
\hline & $4-6 m$ & $\mathrm{C}_{\mathrm{R}}$ & 0,85 \\
\hline & $6-10 m$ & $\mathrm{C}_{\mathrm{R}}$ & 0,95 \\
\hline & $10-30 \mathrm{~m}$ & $\mathrm{C}_{\mathrm{R}}$ & 1 \\
\hline
\end{tabular}


Load Dynamic Methods to Prevent Liquefaction at Yogyakarta International Airport Indonesia

Table 2 Correction Factors of SPT Value

\begin{tabular}{|c|l|c|c|}
\hline Factor & Variabel & Simbol & Corection \\
\hline \multirow{2}{*}{ Sampling Method } & Sampler Standard & $C_{S}$ & 1 \\
\cline { 2 - 4 } & Sampler Standard & $C_{S}$ & $1,1-1,3$ \\
\hline
\end{tabular}

(Source : Youd dan Idriss, 1997)

This factor is generally calculated from Equation 2.

$\mathrm{CN}=\left(\mathrm{Pa} / \sigma^{\prime}{ }_{\text {vo }}\right)^{0.5}$

where:

$\mathrm{Pa}=1 \mathrm{~atm}$ is the same pressure used by $\sigma$ 'vo

$\mathrm{CN}$ value cannot exceed 1.7

Calculate the CRR value with Equation 3 below

$\mathrm{CRR}_{7.5}=\frac{1}{34-(\mathrm{N} 1) 60}+\frac{(\mathrm{N} 1) 60}{135}+\frac{50}{[10 .(\mathrm{N} 1) 60+45]^{2}}-\frac{1}{200}$

Calculate the liquefaction safety factor with Equation 4 below.

$\mathrm{FS}=\frac{C R R}{C S R}$

Normalization of CPT is obtained from Equations 5 and 6 as follows:

$\mathrm{qc}_{1 \mathrm{~N}}=\mathrm{C}_{\mathrm{N}}(\mathrm{qc} / \mathrm{Pa})$

$\mathrm{C}_{\mathrm{N}}=\left(\mathrm{Pa} / \sigma^{\prime}{ }_{\text {vo }}\right)^{\mathrm{n}}$

where:

qc1N = Normalized cone values

$\mathrm{qc}=$ cone resistance

$\mathrm{CN}=$ normalization correction factor

$\mathrm{Pa}=$ Atmospheric pressure, around $100 \mathrm{kPa}$.

$\mathrm{n}=$ Exponents that vary with type, ranging from 0.5 (cleansand) to 1.0 (clay)

Normalized net sand equivalent of N-SPT (qcIN) cs. The Kc value is defined from Equation 7 below.

$\left(\mathrm{q}_{\mathrm{cIN}}\right)_{\mathrm{cs}}=\mathrm{Kc} \cdot \mathrm{q}_{\mathrm{cIN}}$

where:

$\mathrm{Kc}=$ correction factor for grain characteristics

QcIN normalized cone resistance, for clayey sand are corrected against net sand (cs) with price (qcIN)cs with Equations 8 and 9 below.

For Ic $\leq 1,64 \ldots . . \mathrm{Kc}=1,0$

For Ic $>1,64 \ldots . . \mathrm{Kc}=-0,403 \cdot \mathrm{Ic}^{4}+5,581 . \mathrm{Ic}^{3}-21,63 \cdot \mathrm{Ic}^{2}+33,75 \cdot \mathrm{Ic}-17,88$

Calculation of $\mathrm{Q}$ value with exponent value $\mathrm{n}=0.5$ for pure sand and for clay type soil using exponent value use $n=1$. After the type of soil tested has been clacified its type is calculated by Equations 10, 11, 12 and 13.

$I c=[(3.47-\log Q) 2+(1.22+\log F) 2]^{0.5}$

$Q=\left[\left(q_{c}-\sigma_{v o}\right) / P\right]\left(P a / \sigma_{v o}{ }^{\prime}\right)^{n}$

$F=\left[f s /\left(q_{c}-\sigma_{v o}\right)\right] \times 100 \%$

If value of $\left(\mathrm{q}_{\mathrm{cIN}}\right)_{\mathrm{cs}}<211$

CRR7,5 $=\exp \left[\left(\left(\mathrm{q}_{\mathrm{cIN}}\right)_{\mathrm{cs}} / 540\right)+\left(\left(\mathrm{q}_{\mathrm{cIN}}\right)_{\mathrm{cs}} / 67\right)^{2}-\left(\left(\mathrm{q}_{\mathrm{cIN}}\right)_{\mathrm{cs}} / 80\right)^{3}+\left(\left(\mathrm{q}_{\mathrm{cIN}}\right)_{\mathrm{cs}} / 114\right)^{4}-3\right)$

If value of $\left(\mathrm{q}_{\mathrm{cIN}}\right)_{\mathrm{cs}}>211$, so $\mathrm{CRR}_{7,5}=2$ 


\subsection{Dynamic Compaction}

This Dynamic Compaction method was discovered by Menard. This method can save costs in substituting the use of piles (piles) into shallow foundations until the use of certain loads in accordance with an increase in the carrying capacity of the soil. In Indonesia, this method is not widely known. But along with the information that is easily obtained and the comparative factor with other conventional methods that are known, this method can be an option worth considering.

The depth of significant influence on compaction can be estimated using Equation 14.

$$
\mathrm{D}=\left(\frac{1}{2}\right) \sqrt{W H \times h}
$$

where:

$\mathrm{D}=$ depth of compaction $(\mathrm{m})$

$\mathrm{WH}=$ falling load (ton)

$\mathrm{h}=$ high load drop $(\mathrm{m})$

\section{RESEARCH METHODOLOGY}

\subsection{Research Processing}

The analysis and processing of data that has been taken (field test data and laboratory data) is then processed using the Microsoft Excel program for CSR and CRR calculations with the NCEER method.

\subsection{Data Analysis}

Procedure for analyzing SPT data.

1. The soil must be below ground water level (saturated)

2. The next step is to determine the value of the cyclic stress ratio (CSR),

3. By using the value of the soil parameter from the normalization correction factor (N1) 60 , the cyclic resistance ratio (CRR) can be calculated.

4. In the end the safety factor value will be obtained which indicates the potential liquefaction of the land.

5. In this study 6 points of review were used based on SPT data.

CPT data processing analyzes the conus resistance (qc) value of the sondir tool and the value of fs or local friction, which is the resistance arising from friction between two surfaces that move relative to each other.

\section{ANALYSIS AND DISCUSSION}

\subsection{Analysis of Liquidation Potential}

Based on the Map of the Indonesian Earthquake Region SNI 1726-2012 the Kulon Progo area has a PGA value of $0.4-0.5 \mathrm{~g}$ and taken $\mathrm{PGA}=0.4 \mathrm{~g}$.

There are 6 points in the deep boring runway, namely DB-01, DB-02, DB-03, DB-04, DB-05, DB-06. Six sondir point samples are taken, namely CPT-01, CPT-02, CPT-03, CPT07, CPT-09, CPT-11.

\subsubsection{SPT Analysis}

To find out the liquefaction potential, an analysis was carried out as below. The results are obtained as presented in the Table and Graph. 


\section{SPT Data}

Depth of layer $(\mathrm{z}) \quad: 14$ meters

Ground water level $\quad: 3.2$ meters

$\mathrm{a}_{\max } \quad: 0,4 \mathrm{~g}$

Gravity Acceleration $(\mathrm{g}) \quad: 9,81 \mathrm{~m} / \mathrm{s}^{2}$

Weight volume of water $\left(\gamma_{\mathrm{w}}\right): 9,81 \mathrm{kN} / \mathrm{m}^{3}$

\section{Calculation of the Effective Stress}

Total stress $\left(\sigma_{1}\right) \quad=\mathrm{h} \times \gamma$

$$
=2 \times 12,438=24,876 \mathrm{kN} / \mathrm{m}^{2}
$$

Pore pressure $(\mathrm{u})=0 \mathrm{kN} / \mathrm{m} 2$

Effective stress $\left(\sigma_{1}{ }^{\prime}\right)=\sigma-\mathrm{u}$

$$
=24,876-0=24,876 \mathrm{kN} / \mathrm{m}^{2}
$$

\section{Calculation of the stress reduction value $(r d)$}

The stress reduction coefficient indicates the flexibility of the soil profile. To calculate the average price of rd (Whitmann, 1986)

Requirements:

$\mathrm{Rd}=1,0-0,00765 \mathrm{z}$ (for $\mathrm{z} \leq 9,15 \mathrm{~m}$ )

$\mathrm{Rd}=1,174-0,0267 \mathrm{z}($ for $9,15<\mathrm{z} \leq 23 \mathrm{~m})$

Layer 1.

rd $\quad=1,0-0,00765 \times \mathrm{z}$

$$
=1,0-0,00765 \times 2=0,9847
$$

\section{Calculation ofCyclic Stress Ratio (CSR)}

Seed and Idriss (1971) formulated the following equation:

$\mathrm{CSR}=\left(\frac{\tau a v}{\sigma \cdot v o}\right)=0,65\left(\frac{a m a x}{g}\right)\left(\frac{\sigma v o}{\sigma v o \prime}\right) r d$

Where :

amax: earthquake acceleration in the horizontal direction

g: gravityacceleration due to

$\sigma \mathrm{v}$ : total stress and effective stress

rd: stress reduction coefficient

Layer 1

$$
\begin{aligned}
\operatorname{CSR}= & 0,65\left(\frac{\text { amax }}{g}\right)\left(\frac{\sigma v 1}{\sigma v 1^{\prime}}\right) r d \\
& =0,65 \times(0,4)\left(\frac{24,876}{24,876}\right) \times 0,9847=0,256
\end{aligned}
$$

\section{Calculation of Cyclic Resistance Ratio (CRR)}

CRR values can be calculated with the following equation:

$$
C R R=\frac{1}{34-(N 1) 60}+\frac{(N 1) 60}{135}+\frac{50}{(10 x(N 1) 60+45)^{2}}-\frac{1}{200}
$$

where: 
(N1) 60: $\mathrm{N}$ value of SPT corrected to the field testing procedure

Before entering the main formula of the CRR must first calculate the value (N1) 60 using the correction factors to the SPT value

For example.

Energy ratio factor $\left(\mathrm{C}_{\mathrm{E}}\right) \quad: 1,2$ (Automatic Hammer)

Hole diameter factor $\left(\mathrm{C}_{\mathrm{B}}\right): 1$

Rod length factor $\left(\mathrm{C}_{\mathrm{R}}\right) \quad: 0,85$

Factor of sampling method $\left(\mathrm{C}_{\mathrm{S}}\right): 1$

Layer 1

$$
\begin{aligned}
& \left(\mathrm{N}_{1}\right)_{60}=\mathrm{N}_{\mathrm{M}} \times \mathrm{C}_{\mathrm{E}} \times \mathrm{C}_{\mathrm{B}} \times \mathrm{C}_{\mathrm{R}} \times \mathrm{C}_{\mathrm{S}} \\
& =\left(\mathrm{N} \times \mathrm{C}_{\mathrm{N}}\right) \times \mathrm{C}_{\mathrm{E}} \times \mathrm{C}_{\mathrm{B}} \times \mathrm{C}_{\mathrm{R}} \times \mathrm{C}_{\mathrm{S}} \\
& =\left\{N \times\left(\frac{2,2}{1,2+\frac{\sigma \prime v o}{P A}}\right)\right\} \times \mathrm{C}_{\mathrm{E}} \times \mathrm{C}_{\mathrm{B}} \times \mathrm{C}_{\mathrm{R}} \times \mathrm{C}_{\mathrm{S}} \\
& =\left\{18 \times\left(\frac{2,2}{1,2+\frac{24,876}{101,325}}\right)\right\} \times 1,2 \times 1 \times 0,85 \times 1 \\
& =27,9431 \\
& \mathrm{CRR}=\frac{1}{34-(N 1) 60}+\frac{(N 1) 60}{135}+\frac{50}{(10 x(N 1) 60+45)^{2}}-\frac{1}{200} \\
& =\frac{1}{34-27,9431}+\frac{27,9431}{135}+\frac{50}{(10 \times 27,9431+45)^{2}}-\frac{1}{200}=0,3676
\end{aligned}
$$

\section{Calculation of FS}

FS is a value that indicates the potential liquefaction in general is written with

$F S=\frac{C R R}{C S R}$,

where:

If $: F S=\frac{C R R}{C S R}<1:$ means liquefaction

If $: F S=\frac{C R R}{C S R}=1:$ means critical condition

If : $F S=\frac{C R R}{C S R}>1:$ means there is no liquifaction

Layer 1

$$
\begin{aligned}
& F S=\frac{C R R}{C S R} \\
& =\frac{0,3676}{0,2560}=1,4357 \text { (no liquefaction) }
\end{aligned}
$$

Based on the results of the calculation of SPT at point DB-01 obtained a graph like in Figure 3 which contains the $\mathrm{x}$-axis consisting of 3 variables, namely the value of CSR, CRR, and FS and on the $y$ axis is the depth of the bore hole test point on the SPT. Where if the FS value is less than 1 indicates that at that depth experienced a potential liquefaction. At this point the liquefaction potential occurs in soil layers 2 and 3 at depths of 4 - 6 meters. 


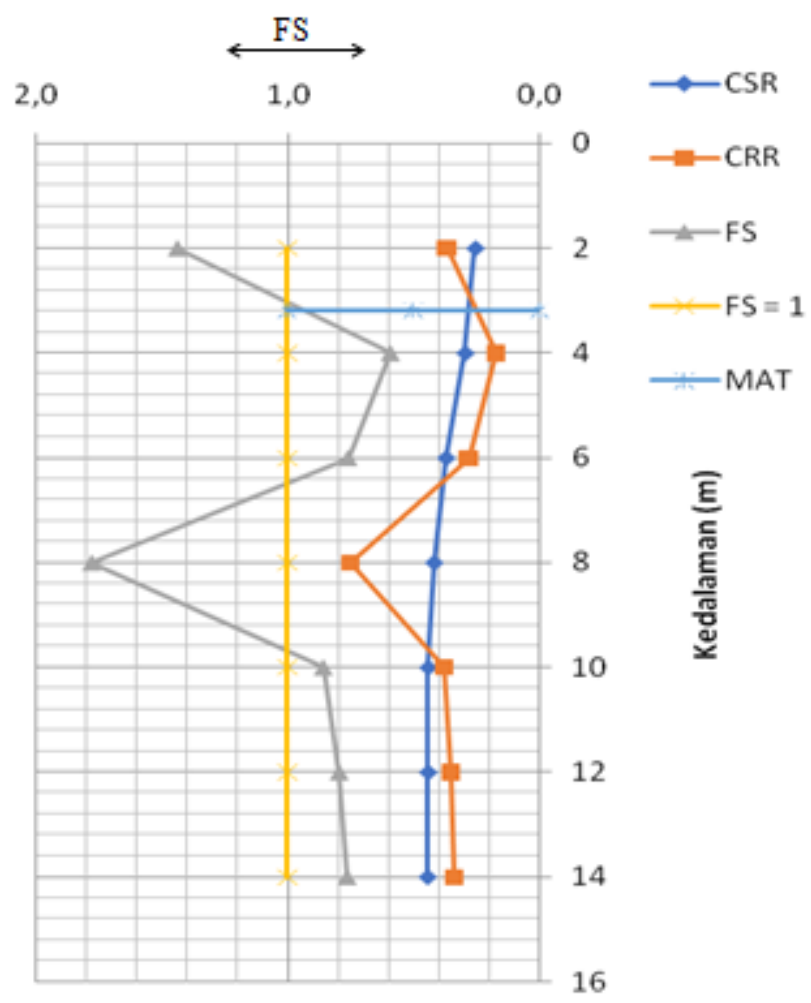

Figure 3 Graph of CSR, CRR, FS vs. Depth (DB-01)

\subsubsection{CPT Analysis}

The field data obtained from the CPT test is cone tip resistance (qc). From the existing qc value, it can be calculated the friction value and the amount of sticking resistance in a soil layer. From the value of end resistance can be calculated CRR value which represents the value of soil resistance to cyclic loads due to earthquake.

For CPT-01

$$
\begin{aligned}
\mathrm{h} & =0,2 \mathrm{~m} \\
\gamma_{\mathrm{d}} & =12,438 \mathrm{kN} / \mathrm{m}^{2}
\end{aligned}
$$

\section{Calculation of effective stress $\left(\sigma^{\prime}\right)$}

Total stresses $\left(\sigma^{\prime}\right)=\mathrm{h}$ x $\gamma=0,2 \times 12,438=2,4876 \mathrm{kN} / \mathrm{m}^{2}$

Pore water pressure $(\mathrm{u}) \quad=0 \mathrm{kN} / \mathrm{m}^{2}$

Effective stress $\left(\sigma_{1}{ }^{\prime}\right) \quad=\sigma-\mathrm{u}=2,4876-0=2,4876 \mathrm{kN} / \mathrm{m}^{2}$

\section{Calculation of the stress reduction( $\mathrm{rd}$ )}

$$
\begin{aligned}
\mathrm{rd} & =1,0-0,00765 \times \mathrm{z} \\
& =1,0-0,00765 \times 0,4==0,99694
\end{aligned}
$$

\section{Calculation of the Cyclic Stress Ratio (CSR)}

CSR

$$
\begin{aligned}
& =0,65\left(\frac{a \max }{g}\right)\left(\frac{\sigma v 0}{\sigma v 0^{\prime}}\right) r d \\
& =0,65 \times(0,4) \times\left(\frac{2,4876}{2,4876}\right) \times 0,99694=0,2592
\end{aligned}
$$




\section{4. $Q$ value Calculation}

The qc value is obtained from CPT-01 data.

$$
\begin{aligned}
& \mathrm{qc}=861,01948 \mathrm{kN} / \mathrm{m}^{2} . \\
& \mathrm{Pa}==101,325 \mathrm{kN} / \mathrm{m}^{2} . \\
& \mathrm{Q}=\left[\frac{\left(q_{c}-\sigma_{v o}\right)}{P_{a}}\right]\left[\left(\frac{P_{a}}{\sigma_{v o}^{\prime}}\right)^{n}\right] \\
& =\left[\frac{(861,0195-2,4876)}{101,325}\right]\left[\left(\frac{101,325}{2,4876}\right)^{0,5}\right]==54,076409
\end{aligned}
$$

\section{F value Calculation}

The fs value is obtained from CPT-01 data in Appendix 2.

$\mathrm{fs}=20,59386 \mathrm{kN} / \mathrm{m}^{2}$.

$$
\begin{aligned}
\mathrm{F} & =\left[\frac{f_{s}}{q_{c}-\sigma_{v o}}\right] \times 100 \% \\
& =\left[\frac{20,5939}{861,0195-2,4876}\right] \times 100 \%=0,023987
\end{aligned}
$$

\section{Calculation of the value of Ic}

$$
\begin{aligned}
\mathrm{IC} & =\left[(3,47-\log Q)^{2}+(1,22+\log F)^{2}\right]^{0,5} \\
& =\left[(3,47-\log 54,076409)^{2}+(1,22+\log 0,023987)^{2}\right]^{0,5}=1,78246
\end{aligned}
$$

\section{Cq value calculation}

$\mathrm{Cq}=\left(\frac{P a}{\sigma_{v o}^{\prime}}\right)^{n}=\left(\frac{101,325}{2,4876}\right)^{0,5}=6,382165$

\section{Calculation of the value of qcIN}

$\mathrm{qcIN}=\mathrm{Cq}(\mathrm{qc} / \mathrm{Pa})=6,382165(861,01948 / 101,325)=54,2331$

Normalized N-SPT net sand mixing coefficient (qcIN) cs

QcIN normalized detergent prices, for concentrated sand were corrected against net sand (cs) with price (qcIN) cs as follows.

$\left(\mathrm{q}_{\mathrm{cIN}}\right)_{\mathrm{cs}}=\mathrm{Kc} \cdot \mathrm{q}_{\mathrm{cIN}}$

where:

Robertson and Wride (1998) shows the value of Kc.

For : Ic $\leq 1,64 \ldots . \mathrm{Kc}=1,0$

For, $\mathrm{Ic}>1,64 \ldots . \mathrm{Kc}=-0,403 \cdot \mathrm{Ic}^{4}+5,581 \cdot \mathrm{Ic}^{3}-21,63 \cdot \mathrm{Ic}^{2}+33,75 \cdot \mathrm{Ic}-17,88$

In the calculation of the value of Ic above, obtained value of Ic $=1.78246$

Ic $>1,64$

$\mathrm{Kc}=-0,403 \cdot \mathrm{Ic}^{4}+5,581 \cdot \mathrm{Ic}^{3}-21,63 \cdot \mathrm{Ic}^{2}+33,75 \cdot \mathrm{Ic}-17,88$

$=-0,403 \cdot 1,78246^{4}+5,581.1,78246^{3}-21,63.1,78246^{2}+33,75.1,78246-17,88$

$=1,09408$

$$
\begin{aligned}
\left(\mathrm{q}_{\mathrm{cIN}}\right)_{\mathrm{cs}} & =\mathrm{Kc} \cdot \mathrm{q}_{\mathrm{cIN}} \\
& =1,09408 \times 54,2331=59,3353
\end{aligned}
$$


Load Dynamic Methods to Prevent Liquefaction at Yogyakarta International Airport Indonesia

\section{9. $C R R$ value calculation}

$\mathrm{CRR}=\exp \left[\left(\left(\mathrm{q}_{\mathrm{cIN}}\right)_{\mathrm{cs}} / 540\right)+\left(\left(\mathrm{q}_{\mathrm{cIN}}\right)_{\mathrm{cs}} / 67\right)^{2}-\left(\left(\mathrm{q}_{\mathrm{cIN}}\right)_{\mathrm{cs}} / 80\right)^{3}+\left(\left(\mathrm{q}_{\mathrm{cIN}}\right)_{\mathrm{cs}} / 114\right)^{4}-3\right]$

$=\exp \left[(59,3353 / 540)+(59,3353 / 67)^{2}-(59,3353 / 80)^{3}+(59,3353 / 114)^{4}-3\right]$

$=0,087122$

Based on the value (qcIN) cs obtained is 59.3353, according to Idriss and R.W. Boulanger (1996) is obtained the CRR7.5 value is as follows:

If : $\left(\mathrm{q}_{\mathrm{cIN}}\right)_{\mathrm{cs}}<211$

CRR7,5 $=\exp \left[\left(\left(\mathrm{q}_{\mathrm{cIN}}\right)_{\mathrm{cs}} / 540\right)+\left(\left(\mathrm{q}_{\mathrm{cIN}}\right)_{\mathrm{cs}} / 67\right)^{2}-\left(\left(\mathrm{q}_{\mathrm{cIN}}\right)_{\mathrm{cs}} / 80\right)^{3}+\left(\left(\mathrm{q}_{\mathrm{cIN}}\right)_{\mathrm{cs}} / 114\right)^{4}-3\right]$

If : $\left(\mathrm{q}_{\mathrm{cIN}}\right)_{\mathrm{cs}}>211$, so $\mathrm{CRR}_{7,5}=2$

\section{FS Calculation}

$\mathrm{FS}=\frac{C R R}{C S R}=\frac{0,087122}{0,25920}=0,33611<1$ (lequefaction)

Based on the results of the calculation of CPT at the CPT-01 point, the graph as shown in Figure 4.

FS

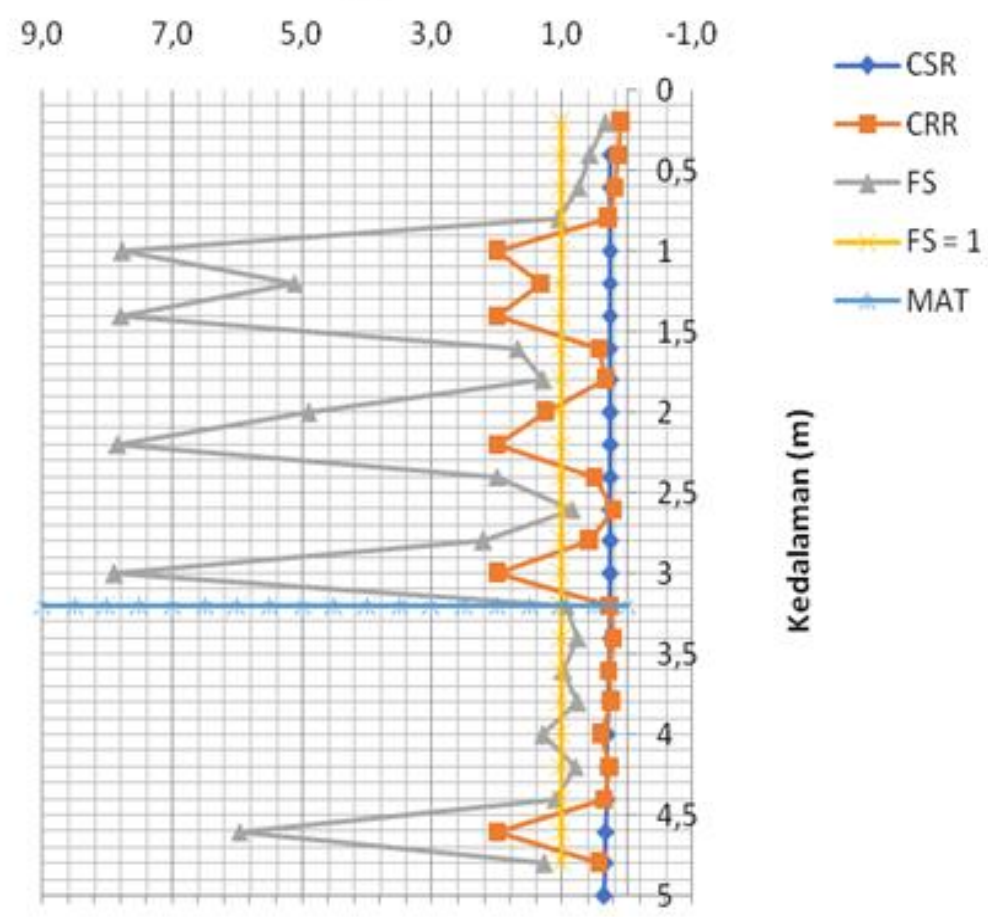

Figure 4 Graph of CSR, CRR, FS vs. Depth (CPT-01)

\subsubsection{Analysis of Potential Liquidation after Load Dynamic Compaction}

\section{Calculation for SPT}

The results of the analysis of liquefaction potential for SPT after load dynamic co(DG01)mpaction are presented inTable 3 and Figure 5 below 
Edy Purwanto and Annisa Yaumil Akhiri

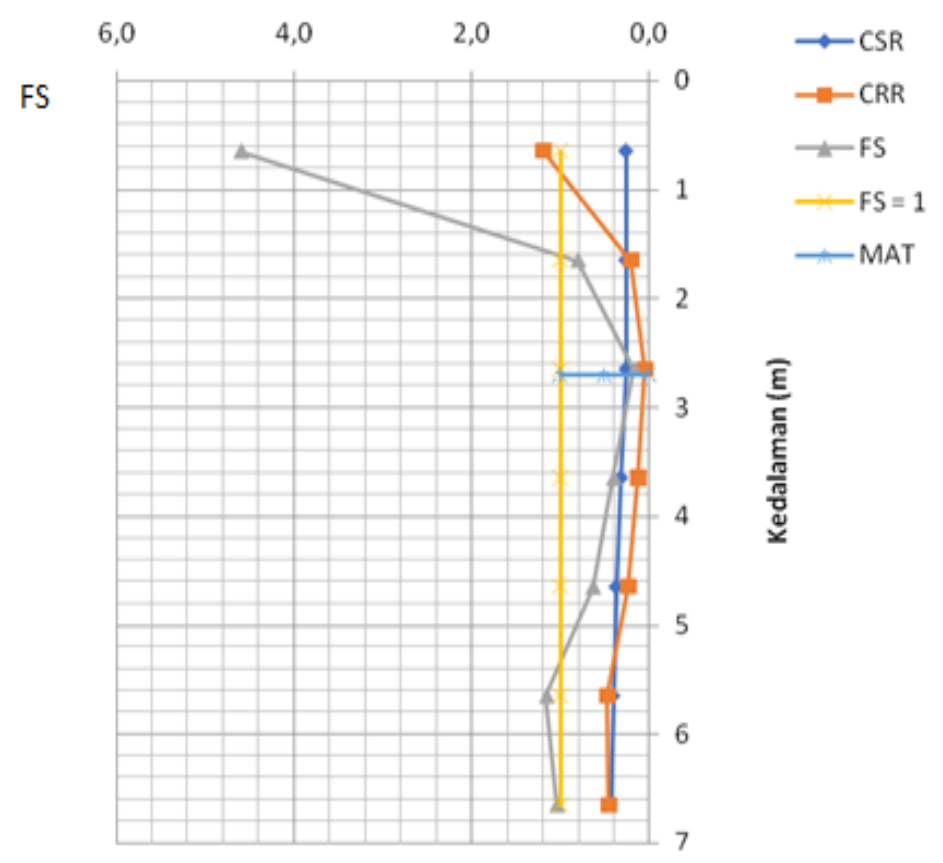

Figure 5 Graph of CSR, CRR, FS vs. Depth (DB-01)

\section{Calculation for CPT-01}

The results of the analysis of liquefaction potential for CPT-01 after load dynamic compaction are presented in Table 4 and Figure 6 below.

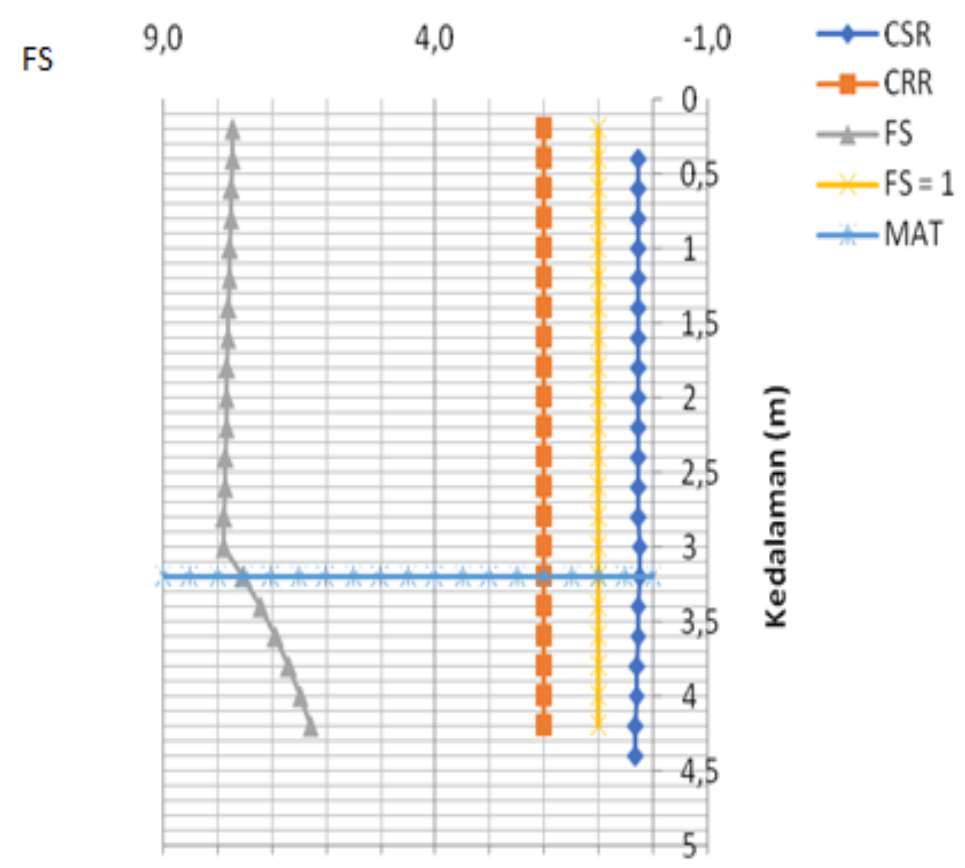

Figure 6 Graph of CSR, CRR, FS vs Depth (CPT-01)

The results of the analysis for the SPT test and CPT test were carried out without dynamic loading (before compaction) and with dynamic loading (after compaction) are presented in Table 3 below 
Load Dynamic Methods to Prevent Liquefaction at Yogyakarta International Airport Indonesia

Table 3 Recapitulation of SPT-01 Calculation Before and After Compaction

\begin{tabular}{|c|c|c|c|c|c|c|c|c|c|c|}
\hline Depth & \multicolumn{3}{|c|}{ Original soil } & Status & Depth & \multicolumn{3}{c|}{ After Compaction } & Status \\
\hline & CSR & CRR & FS & & & CSR & CRR & FS & \\
\hline 2 & 0,256 & 0,367 & 1,435 & NL & 0,65 & 0,258 & 1,188 & 4,592 & NL \\
\hline 4 & 0,296 & 0,174 & 0,589 & L & 1,65 & 0,256 & 0,206 & 0,804 & NL \\
\hline 6 & 0,372 & 0,282 & 0,757 & L & 2,65 & 0,254 & 0,043 & 0,170 & NL \\
\hline $\mathbf{c}$ & 0,420 & 0,747 & 1,777 & NL & 3,65 & 0,315 & 0,126 & 0,401 & NL \\
\hline \multirow{1}{0}{} & 0,443 & 0,379 & 0,855 & NL & 4,65 & 0,367 & 0,232 & 0,633 & NL \\
\hline 10 & 0,444 & 0,352 & 0,792 & NL & 5,65 & 0,403 & 0,466 & 1,155 & NL \\
\hline 12 & 0,446 & 0,339 & 0,761 & NL & 6,65 & 0,432 & 0,449 & 1,040 & NL \\
\hline- & - & - & - & - & 7,65 & 0,000 & 0,439 & 0,952 & NL \\
\hline- & - & - & - & - & 8,65 & 0,461 & 0,429 & 0,882 & NL \\
\hline- & - & - & - & - & 9,65 & 0,000 & 0,419 & 0,834 & NL \\
\hline
\end{tabular}

Table 4 Recapitulation of CPT-01 Calculation before and After Compaction

\begin{tabular}{|c|c|c|c|c|c|c|c|c|}
\hline Depth & \multicolumn{3}{|c|}{ Soil Original } & Status & \multicolumn{3}{c|}{ After Compaction } & Status \\
\hline & CSR & CRR & FS & & CSR & CRR & FS & \\
\hline 0,2 & & & & & & & & \\
\hline 0,4 & 0,259 & 0,087 & 0,336 & L & 0,259 & 2,000 & 7,716 & NL \\
\hline 0,6 & 0,259 & 0,147 & 0,569 & L & 0,259 & 2,000 & 7,728 & NL \\
\hline 0,8 & 0,258 & 0,192 & 0,742 & L & 0,258 & 2,000 & 7,740 & NL \\
\hline 1 & 0,258 & 0,273 & 1,057 & NL & 0,258 & 2,000 & 7,752 & NL \\
\hline 1,2 & 0,258 & 2,000 & 7,764 & NL & 0,258 & 2,000 & 7,764 & NL \\
\hline 1,4 & 0,257 & 1,316 & 5,117 & NL & 0,257 & 2,000 & 7,776 & NL \\
\hline 1,6 & 0,257 & 2,000 & 7,788 & NL & 0,257 & 2,000 & 7,788 & NL \\
\hline 1,8 & 0,256 & 0,431 & 1,679 & NL & 0,256 & 2,000 & 7,800 & NL \\
\hline 2 & 0,256 & 0,330 & 1,290 & NL & 0,256 & 2,000 & 7,812 & NL \\
\hline 2,2 & 0,256 & 1,254 & 4,906 & NL & 0,256 & 2,000 & 7,824 & NL \\
\hline 2,4 & 0,255 & 2,000 & 7,836 & NL & 0,255 & 2,000 & 7,836 & NL \\
\hline 2,6 & 0,255 & 0,507 & 1,990 & NL & 0,255 & 2,000 & 7,848 & NL \\
\hline 2,8 & 0,254 & 0,215 & 0,846 & L & 0,254 & 2,000 & 7,861 & NL \\
\hline 3 & 0,254 & 0,561 & 2,209 & NL & 0,254 & 2,000 & 7,873 & NL \\
\hline 3,2 & 0,254 & 2,000 & 7,885 & NL & 0,254 & 2,000 & 7,885 & NL \\
\hline 3,4 & 0,266 & 0,249 & 0,937 & L & 0,266 & 2,000 & 7,518 & NL \\
\hline 3,6 & 0,278 & 0,212 & 0,762 & L & 0,278 & 2,000 & 7,202 & NL \\
\hline 3,8 & 0,289 & 0,283 & 0,979 & L & 0,289 & 2,000 & 6,926 & NL \\
\hline 4 & 0,299 & 0,228 & 0,764 & L & 0,299 & 2,000 & 6,685 & NL \\
\hline 4,2 & 0,309 & 0,402 & 1,300 & NL & 0,309 & 2,000 & 6,471 & NL \\
\hline 4,4 & 0,318 & 0,255 & 0,800 & L & 0,318 & 2,000 & 6,281 & NL \\
\hline 4,6 & 0,327 & 0,365 & 1,116 & NL & & & & \\
\hline 4,8 & 0,336 & 2,000 & 5,957 & NL & & & & \\
\hline 5 & 0,344 & 0,439 & 1,277 & NL & & & & \\
\hline
\end{tabular}

$L=$ Liquifaction hapenned,$N L=$ No Liquifaction

\section{CONCLUSION}

- Based on the SPT data, the result shows that the comparison between CRR and CSR values in several layers of land at each point of view has a liquefaction potential at a depth of 2-6 meters.

- Based on the CPT data, the result shows that the liquefaction potential occurs at a depth of - 0.4.m to $-4.8 \mathrm{~m}$ from the ground level 
- Based on the SPT and CPT data after compaction, the result shows that all points of view obtained is safe results from potential liquefaction.

- Dynamic load method test can prevent liquefaction on sandy soil

\section{ACKNOWLEDGEMENTS}

The authors wish to gratefully acknowledge the contribution and cooperation of Department of Public Works and Public Housing Yogyakarta.

\section{REFERENCES}

[1] Annisa Yaumil Akhiri (2019) "Evaluation of Soil Reinforcement Using Dynamic Compaction Method for Liquifaction Restraining", Civil Engienering Department, Universitas Islam Indonesia Yogyakarta Indonesia

[2] Dwianta (2015) "StudiParametrikPotensiLikuifaksi dan PenurunanPermukaan Tanah Berdasarkan Uji Sondir". Diperoleh hasil Magnitudo dan percepatan gempa yang lebih besar menyebabkan lapisan tanah banyak mengalami likuifaksi dan memicu kerusakan di permukaan tanah. Potensi likuifaksi tidak hanya dipengaruhi oleh parameter seismik, tetapi juga oleh litologi tanah.

[3] Hatmoko, J.T. (2016). Dinamika Tanah dan Liquefaction, Penerbit Cahaya Atma Pustaka, Yogyakarta, Indonesia.

[4] Lestari, Rizka Amalia. 2018. Analisis Potensi Likuifaksi Akibat Gempa Bumi Menggunakan Data SPT dan CPT. Universitas Islam Indonesia. Yogyakarta.

[5] Muntohar, Agus Setyo. 2012. Studi ParametrikPotensiLikuifaksi dan PenurunanPermukaan Tanah Berdasarkan Uji Sondir. Universitas Muhammadiyah Yogyakarta. Yogyakarta.

[6] Seed, H.B. 1982. Ground Motions and Soil Liquefaction during Earthquakes, Earthquake Engineering Research Institute. Pasadena California, USA.

[7] SNI 1726-2012. 2012. Standar Perencanaan Ketahanan Gempa Untuk Struktur Bangunan Gedung dan Non Gedung. Badan Standarisasi Nasional. Jakarta.

[8] Seed, H.B. and Idriss. 1971. Simplified Procedure for Evaluation Soil Liquefaction Potential, Journal of soil mechanics, and foundation, Division, ASCE, vol.97. No.9, pp. 1249 - 1273.

[9] Srikit (2019). Analisis Potensi Likuifaksi Berdasarkan Distribusi Butir dan Data N-SPT. Program Study Teknik Sipil, FTSP-UII, Yogyakarta.

[10] Sun, J.I., Golesorkhi, R dan Seed H.B. 1988. Dynamic Moduli and Damping Ratio for Cohesive Soils. Universitas California. Berkeley.

[11] Tri Hatmoko, John. 2016. Dinamika Tanah dan Liquefaction. Cahaya Atma Pustaka. Yogyakarta. 